\title{
LILRB2 wt Allele
}

National Cancer Institute

\section{Source}

National Cancer Institute. LILRB2 wt Allele. NCI Thesaurus. Code C102794.

Human LILRB2 wild-type allele is located in the vicinity of $19 q 13.4$ and is approximately 7 $\mathrm{kb}$ in length. This allele, which encodes leukocyte immunoglobulin-like receptor subfamily $\mathrm{B}$ member 2 protein, plays a role in binding to class I MHC antigens and the regulation of T-cell responses. 